吉冨勝報告「グローバル経済危機の歴史的性格一金融的側 面を中心として」へのコメント

帝京大学 安保哲夫

吉冨報告「グローバル経済危機の歴史的性格」は，1990年代に日本とアジア を焦点として広がった世界経済の危機的様相について，1929年に始まるアメリ カの大恐慌と比較しつつ, 平板な規制緩和論などの多数派とは異なるシャープ な切り口で，金融的側面を中心にダイナミックな分析をしてみせた。

その中心部分を氏は, クレジットクランチ・アプローチと呼び, マネーサプ ライの動向を重視する通説に対し，銀行の信用収縮に焦点を当てる視角から経 済危機を説明しょうとしている1）これは，経済危機の進展のプロセスにおい て，金融情報の処理の仕方を問題にし，信用の仲介機関としての銀行の中小企 業などに対する信用リスクの高まりからクレジットクランチが生じ，それが金 融デフレの主因になるとする議論である。これは，ことに 80 年代末以後の日本 経済のバブル化とその崩壊過程の解明に有効な新視点を提供しており, 高く評 価される。ただそれは，金融のテクニカルな細部にわたる議論を含み，評者が その全てについて正確にフォローできるとは思わないが，別の面からの批評も 可能であろう。以下では, 吉冨氏の都合で報告要旨の詳細が本紙に揭載されな いという事情を考慮し，氏の報告のポイントを評者なりに紹介しつつ，それに 対するコメントを述べることにしたい。

氏の報告は，大きく2 点に分かれており，その一つがアメリカ大恐慌に関す るものである。氏は，かって大著『アメリカの大恐慌』を著したこの分野の 研究の草分けでもあり, 現局面を歴史的な視野から照射することのできる数少 ない適役の一人である。本報告での基本線は，預金保証機構を欠く金融制度の

E-mail : abo@main.teikyo-u.ac.jp 
吉富勝報告「グローバル経済危機の歴史的性格一金融的側面を中心として」へのコメント（安保）

下で，30年銀行恐慌の地方への波及が預金取付けを媒介にマネーサプライの大 幅減少を招き，そのプロセスにおける銀行の信用収縮が企業，特に中小企業へ の貸し出しの削減となって，それが倒産の連鎖，大恐慌への発展につながると いう筋道である。そのさいポイントは，マネーサプライの減少に伴って，リス クの高い一般社債などとリスクのない連邦債の間の「金利格差」が広がるとい うかたちで信用のリスク構造が高まり，銀行が融資選別を強めて信用収縮の第 2 波が生じたことが，大恐慌に発展したクリテイカルな側面だとされる。

それ自身は，金融危機が産業経済の実体部分を巻き込んで経済危機に発展す る動態的なメカニズムを問題にしており，そのプロセスの解明は危機の内容の 正確な理解と，従ってまたそのような事態に対する的確な政策的対応にとって， 有効性の高い一つのアプローチであると評価できる。しかしそれだけで，この 世界史的にみても未曾有の規模と深さをもった大恐慌のもっとも特徽的な性格 が明らかになるであろうか。このようなクレジットクランチは，特にこの時期 までの経済危機には多かれ少なかれ生じていたであろうからである。そうした 分析モデルは, 景気変動過程に繰り返し現れる急激な落ち込みを解明する論理 としては有効性が高いとしても，30年代アメリカの大恐慌や90年代の日本の長 期経済不振の原因論としては，不十分といわざるをえない。

私見では，アメリカの大恐慌を他の循環的な変動と区別する最大の要因は, W.A.ブラウン, C.P.キンドルバーガーなども強調しているように光，中心国の イギリスからアメリカへの交替に伴う世界経済の構造的不安定に由来するもの と考えられる(覇権安定論あるいは筆者のいう「中心国論アプローチ」 $\left.{ }^{4)}\right) 。 そ$ のさい, これはキンドルバーガーや吉冨氏も前著などで指摘しているアメリカ の孤立主義的な対外経済政策の影響や，賠償一戦債問題といった第一次大戦の 深刻な後遺症なども欠かすことは出来ない。それらに加えていま一つ，アメリ カの株式崩壊，信用収縮に続く金融危機を実体経済の大反落につなげ，またこ れを30年代を通して長引かせ，世界を巻き込んで大不況の時代をつくりだした アメリカ国内の隠れた一大原因として，アーント，ローゼノフなどが主張して 
いる「信認」ないし「ビジネス・コンフィデンス」亦失の問題も決して無視で きないものであろう 5)。それは，景気循環の中である範囲を超えた大きな变動 や振れを人々の心理的な要因によって説明しょうとするものである。この時期 のアメリカの場合は, 株式崩壊後の景気政策とそれに関連した社会改革をめぐ って, F.D.ルーズベルト新政権と保守的な産業界の認識が対立し, 企業サイド の投資ビヘビアーにおける先行き悲観論が容易に払拭できなかったという事情 を重視するのである。なおこの理論は, 次にみるように, 90年代日本経済の長 期不振を説明する観点としても極めて有用性が高いと思われる。

本報告のいま一つの論点は, 今回の日本経済のバブル化とその崩壊のメカニ ズムに関するユニークな議論である。やはり上述のクレジットクランチ・アプ ローチが採用されているが，ここでは，金融のバブル化にいたるプロセスにお ける資産インフレのメカニズムの解明にもかなりカ点がおかれている。通説が， 日銀・政府による金融緩和政策の結果としてのマネーサプライの大膨張から資 産インフレを説いているのに対して, なぜこのマネーが一般物価のインフレに ではなく，資産に回ったのかという設問は，まさに要点をついている。そもそ も氏のこの議論の基本には, その著書の中の説明も含めていえば6), 通貨膨張 に先立って土地，株式取引を通じた資産インフレが進行していたという理解が ある。そのうえで氏は, 80 年代後半に生じた大企業における内部留保增大が, 一方では, 金融自由化, 規制緩和の進行ともあいまって, これら企業の銀行離 れを促進して銀行を不動産などハイリズク融資に走らせ, 他方では, メインバ ンク制によるモニター機能を失った企業自身の過剩な設備投資を招来してしま ったとする。そして地価暴落による土地の担保価值低下によって，ノンバンク などをへて大澎張していた銀行債権が不良化したとき, やはり銀行の選別融資 による大規模な信用収縮が生じた。ポイントは，企業の手持ち資金の膨張に対 して銀行側からのコントロール能力が低下した点にあり，これに注目した吉冨 氏の洞察力は卓越している。たた，そのさいなぜ銀行資金が主に資産に流れる ことになったのかは氏も明らかにしていない。それで一般物価のインフレにな 
吉冨勝報告「グローバル経済危機の歴史的性格一金融的側面を中心として」へのコメント（安保）

らない理由を十分説明したことになるであろうか。

いったん資産市場に資金が流入し始めると，ますますキャピタルゲインを求 める資金を吸収して投機的プロセスが自己運動を展開するのはわかるが，それ にしても，その資金の一部がモノに向かわない理由は別に説明する必要があろ う。やはりモノの供給に余力があったというしかないであろうが，そのルート や要因は様々でありうる。1920年代末のアメリカ経済は, 国内に供給余力があ るのに(つまりなお実体経済の過熱化はみられない), 内外の資本蓄積の停滞 の結果形成された余剰資金により資産インフレが生じたケースであり，80年代 末の日本は, 国内供給余力に限界がみえ始めたものの, 飽食時代における日常 品需要の伸びの鈍化と, グローバル化の進展による国境を越えたモノとサービ スの迅速な輸入一競争の範囲とスピードの画期的変化一などが重なって, 需給 の大きなギャップは出来にくくなったケースといえよう。

さらに90年代のアメリカのように，一部情報技術関連商品を別にして，景気 の超過熱化によって生じている巨大な需給ギャップが, 日本, アジアなど海外 の供給余力を背景に迅速な輸入によって埋め合わされて, 恐るべき貿易・経常 赤字額とその結果としての雪だるま式対外債務を積み上げつつも，それによる ドル割高化も寄与して, 当面一般物価の “奇跡的安定” が維持され, それが株 式など資産インフレへの政策的対応を決定的に遅らせるといった場合もある。 関連して，吉冨氏はこのアメリカの景気動向については必ずしも悲観的ではな い。大会当日の評者への回答の中で,アメリカでは, アジアの場合のような 「ダブルミスマッチ」（短期借り・長期貸しとドル建て債務という状況の下で短 期間に巨額の返済を迫られると, 現地通貨建てで返済負担が急増し, さらに現 地通貨急落という悪循環に陥ること）は起こらないから，ドルと株の悪循環的 急落が実体経済への深刻な悪影響を引き起こすことはない，としていた。また その著書において，もちろん株式ブーム崩壊による世界的デフレ化の危険性に 触れつつも，情報技術革新，機関投資家による新しいコーポレート・ガバナン スなど90年代アメリカ経済のダイナミックな発展の側面を強調している7)。し 
かしその反面において, 現在のアメリカ好景気の致命的弱点ともいうべき，上 述のような対外不均衡の側面にほとんど触れることがないのは，理解に苦しむ ところである。

さて，バブル崩壊後の日本経済についても，90年代を通じた経済不振の特徵， ことにそれが経常黒字と大幅貯蓄増を伴いつつ10年間にもわたって継続した点 などは，かなり特殊な多面的要因の複合的産物としてしか説明できないであろ う。吉冨氏の議論のほかにも, さらにいくつかの有力な論点がありうる。ひと つは, ブレトンウッヅ体制崩壞後の変動相場制下におけるアメリカの通貨政策 の影響で，為替大変動，ことに円高圧力がひ弱い景気回復の芽にいかに決定的 な打撃を与えたかは，95年春の円急騰時をみれば明らかである。さらに市場主 義的な規制緩和一構造改革論の影響も少なくない。日本社会における構造改革 の必要性と景気政策とを混同して，90年代には何回か景気回復の局面があった にもかかわらず，まだ構造改革ができていないから本物ではないといった悲観 論が繰り返し唱えられ，ビジネスとことに消費者の先ゆき「信頼感」を損ねて きたのである。そうした点をもっとも端的に示しているのが，吉冨氏もその著 書で指摘しているが8)，97年11月の大手金融機関救済放棄の決定とその後の惨 憺たる結果である。

以上のように，吉冨氏の議論は，戦間期のアメリカ，80年代末以降の日本, 本報告では触れられなかったアジア金融危機などについて, クレジットクラン チ・アプローチを基本的分析モデルとしつつこれにユニークな洞察を加えて， マネーサプライなどで測る単純な算術式景気循環論に対して, 群を抜いた説明 力を示している。ただそれだけに，その信用・金融論に傾斜した鋭い切り口が， 他面では各経済大变動を特徴づける歴史的・国際的・社会的な分析の視野を狭 めていることも指摘せざるをえない。ことに世界経済的な視野が意外なほどに 限定されている点は，大恐慌の研究以来ほぼ一貫していると思われるが，グロ ーバル化の影響が顕著な現代における分析手法としてその制約性を問題にする のは，無いものねだりであろうか。 
吉冨勝報告「グローバル経済危機の歴史的性格一金融的側面を中心として」へのコメント（安保）

[注]

1 ）吉冨勝（1998）『日本経済の真実』東洋経済新報社, 第 3 章など

2 ）吉富 (1965)『アメリカの大恐慌』日本評論社

3 ) Brown, W.A., Jr. (1940), The International Gold Standard Reinterpreted, 1914-1934, NBER ; キンドルバーガー, C.P. : 石崎・木村訳（1982年）『大不況下の世界』東京大 学出版会

4 ）安保哲夫（1984）『戦間期アメリカの対外投資』東京大学出版会

5 ）アーント, H.W. : 小沢他訳『世界大不況下の教訓』東洋経済新報社 ; Rosenof, T. (1975), Dogma, Depression, and the New Deal, NY: Kennikat Press

6 ) 吉富 (1998), 第 2 章など

7 ) 吉富 (1998), 第6 章

8 ) 吉冨 $(1998)$, 第 3 章

\section{〈編集部からのお知らせ $>$}

吉富勝氏（アジア開発銀行研究所所長）には，第58回全国大会共通論題にお いて「グローバル経済危機の歴史的性格一金融的側面を中心として」と題する ご報告をいただき，共通論題での議論を盛り上げる上で大きく貢献していただ きました。非会員のお立場にもかかわらず，ご公務多忙を極める中，大変貴重 なご報告をいただいたことに対して，深甚より感謝を申し上げる次第です。大 会当日，あいにく吉富勝氏報告についての録音テープが用意されていなかった ため，報告者ご本人に原稿をご執筆していたたくことが困難となりました。こ ちらの不手際を報告者にお詫び申し上げますとともに，会員の方々には，今回， 誠に異例ではございますが，共通論題報告の原稿掲載を割愛せざるを得なくな りました事情につきまして，何とぞご理解賜りますよう，お願い申し上げる次 第です。吉富氏の報告内容につきましては, 討論者の安保哲夫会員による上記 の詳細なコメントをお読みいただければ,その概要がほぼご理解頂けると存じ ます。なお参考までに，プログラム委員会が吉冨勝氏のご了承を得て作成した 報告要旨が第58回全国大会『報告要旨集』に掲載されておりますので, 以下, 
それを再録させていただきます。

\section{I．アジアの金融危機の原因と本質}

（1）アジア金融危機が投げかけた数々の大問題

（2）資本収支危機と経常収支危機の比較

(1)問題の所在

(2)経常収支危機とは

(3)資本収支危機の発生メカニズム

(3) ダブル・ミスマッチ

（4）資本収支危機説をめぐる論争点

\section{II. 経済危機への転化}

（1）双子の金融危機がマクロ経済に及ぼす破滅的影響

（2）「クローニー資本主義論」の限界

（3）IMF処方箋の今後のあり方

(1) IMF処方嘎のいくつかの問題点

(2)必要な新しい処方箋

（4）アジア危機の世界的影響

(1)世界の貿易収支への影響

(2)ロシアの金融危機

III. グローバリゼイションが生み出す新しい問題

（1）グローバリゼイションと国際化との基本的相違

（2）金融のグローバル化

(1)グロスとネットの国際資本移動の違い

(2)通貨危機の世界的「伝染」

(3)巨大ヘッジファンドの大失敗

（3）資本と労働の分配対立の激化 